\title{
Bond behavior of self consolidating concrete
}

\section{Estudio de la adherencia del concreto autocompactante}

\author{
Ana C. P. Santos (Main and Contact Author) \\ Universidade Federal da Integração Latinoamericana. Escola de Engenharia. \\ Av. Paraná, 7879. Casa 14-2416. Foz do Iguaçu, Pr. Brasil. +00 55 85868-030. \\ ana.santos@unila.edu.br
}

\section{Antonio Aguado}

Universitat Politecnica de Catalunya. Departamento de Ingeniería de la Construcción.

antonio.aguado@upc.edu

\section{Noé Villegas}

Universidade Federal da Integração Latinoamericana. Escola de Engenharia.

noe.flores@unila.edu.br

Manuscript Code: 483

Date of Acceptance/Reception: 09.07.2016/16.10.2014

\begin{abstract}
The new generation of innovative projects has led to the use of greater amounts of reinforcement and the development of concrete with specific characteristics. It is necessary to use a material that ensures the uniformity of the cross section, as well as the adherence of the existing reinforcement, and due to this, the self-consolidating concrete becomes an technique alternative has great potential to achieve these properties. The aim of this paper is to analyze the bond behavior of self-consolidating concrete that was obtained by means of the Beam Test performed within a large experimental campaign of characterization. Four types of SCC were studied with two strength levels (40 MPa and 60MPa) and two different types of granular skeletons, using two specimens at each age $(3,7$, and 28 days). All specimens were tested with a corrugated steel bar $10 \mathrm{~mm}$ in diameter. The results show that the adhesion tension independently of resistance presents a rapidly evolving at 7 days reached $95 \%$ of the total adhesion by 28 days.
\end{abstract}

Key words: Bond behavior, self-consolidating concrete, strength, beam-test, granular skeleton.

Resumen

La necesidad de proyectos innovadores ha conducido al empleo de mayores cuantías de armadura y al desarrollo de concretos con características especiales. Para ello, se hace necesario el empleo de un material que garantice la homogeneidad de la sección transversal, así como, la adherencia de la armadura existente; en este sentido, el concreto autocompactante se torna una alternativa técnica con gran potencial para atender esas propiedades. El objetivo de este trabajo es analizar los resultados de la resistencia de adherencia del concreto autocompactante obtenidos en una amplia campaña experimental. Se ha trabajado con dos niveles de resistencia a la compresión (40 y $60 \mathrm{MPa}$ ) y con dos esqueletos granulares distintos. Se ha empleado el ensayo de la viga (UNE 36740: 1998) para medir la tensión de adherencia a 3 edades diferentes (3, 7 y 28 días). Todas las probetas fueron ensayadas con una barra corrugada de acero de $10 \mathrm{~mm}$ de diámetro. Los resultados muestran que la tensión de adherencia independientemente de la resistencia, presenta una evolución rápida, alcanzando a los 7 días un 95\% del total de la adherencia a los 28 días.

Palabras Claves: Adherencia, concreto autocompactante, resistencia, ensayo de la viga, esqueleto granular.

Introduction

Bond behavior is an essential feature of reinforced concrete, considering the concrete and reinforcement must act together to absorb the stresses. Forces are transferred between both materials by two different ways: the adhesion and the friction. This behavior in reinforced concrete elements has decisive importance relative to load capacity and service life. Beyond, this is a requirement for calculating the anchorage lengths of steel bars, deflections to control crack width and minimum reinforcement.

Currently, the importance of bond behavior study is receiving increase importance due to certain researches results conducted at the end of eighties decade generated some uncertainty about safety levels calculated by international standards (Herrero, 2000). The new additives types development and the growing contribution of additions to concrete requires a basic properties review of bond behavior as project regulations and calculation for these new concrete's types 
(Mori, Aguado and Renófilo, 2004; Mori and Aguado, 2005) such as self-compacting concrete (SCC) (Santos, Ortiz-Lozano, Villegas and Aguado, 2015). The use of very powerful superplasticizers and a high fines content makes SCC flowable.

Although the SCC has been developed at the end of the eighties, research on bond behavior began at the end of nineties decade, the different studies do not all come to the same conclusions (Valcuende and Parra, 2009). Sonebi and Bartos (1999) conducted a comparative study between the SCC and conventional vibrated concrete (VC), they obtained bond stress values $16 \%$ to $40 \%$ higher for the SCC. According to Gibbs and Zhu (1999) this difference are less than $4 \%$, whereas for Wang (2005) they are about 9\%, for Zhu, Sonebi and Bartos (2004) between 10-40\% and for Collepardi, Borsoi, Collepartdi and Troli (2005) are about 70\%.

Schiessl and Zilch (2001) verified the influence of casting direction is significantly lower in SCC than VC. König, Holschemacher, Dehn and Weibe (2001) concluded SCC has a bond relative strength higher than CV despite its high amount of binders. Garzón, Almeida Filho, El Debs and El Debs (2008) also obtained a better bond strength in SCC when compared with similar mechanical conditions of VC. Desnerck, Taerwe and De Schutter (2007) using the beam-test, observed the same compressive strength, and it was found SCC and CV presents similar bond tensions, but if evaluation is made by constant water/cement ratio, the SCC bond tension is quite superior to VC. Silva, Burgos, Valencia, Delvasto and Alvarez (2013) observed various mechanical properties of SCC are directly related to the packaging of granular skeleton. Almeida Filho, Barragán, Casas and El Debs (2008) noticed the same behavior for SCC and VC, correlating a higher bond stress to a higher elasticity modulus. In order to throw light on bond performance of SCC at early ages, the aim of this paper is to present the results of beam-test obtained in a wide experimental characterization SCC, developed in Universitat Politècnica de Catalunya, Spain.

Methodology

\section{Test methods}

There are two main experimental test methods to performance the bond behavior of steel bars embedded in a concrete matrix: the beam test (AENOR, 1998) and the pull-out test (RILEM TC, 1992). Pull-out test is the most common due to the ease of fabricating the test specimens and performing the test. This test is run by supporting the concrete and applying tension to the reinforcing bar until failure measuring the tensile force and displacement.

The principal criticism regarding this testing method is that it does not produces real solicitation conditions, in which the bending moment and shear force (very important on the adherence behavior) are absent on this methodology. Otherwise, the beam test is more complex, because it uses a reinforced specimen. This method consists to apply a solicitation over the rebar, with the purpose to measure the bond behavior between the concrete and rebar. In addition, it permits to eliminate variations and presents real conditions of the bending moment and shear force, obtaining absolute results. The beam test was adopted in this study.

\section{Beam test}

The beam specimen suggested by the Spanish standard UNE 36740:1998 is adopted, and the sample size is shown in Figure 1. Each specimen comprises two halves of the beam, interconnected at the bottom by one deformed steel bar, each of $12 \mathrm{~mm}$ diameter and $1050 \mathrm{~mm}$ length. A steel hinge is provided near the top to allow the concrete's blocks rotation. To avoid the partial extrusion of the load end and the support reaction's effect, unbounded sectors are set at both, load and support ending. The reinforcement's bond length had $120 \mathrm{~mm}$ each of the two half-beam blocks.

The test consists in applying a bending moment to the beam until complete adhesion rupture in each of its half beams, and simultaneously measuring the bar's displacement. This standard focuses on the steel bars bond behavior's characterization, providing a standard concrete. However, this study has changed the test's approach, fixing the steel bar constant and changing the concrete mix. All preparation steps followed the recommendations of the UNE 36740 (1998), except the vibration that has not been done. 


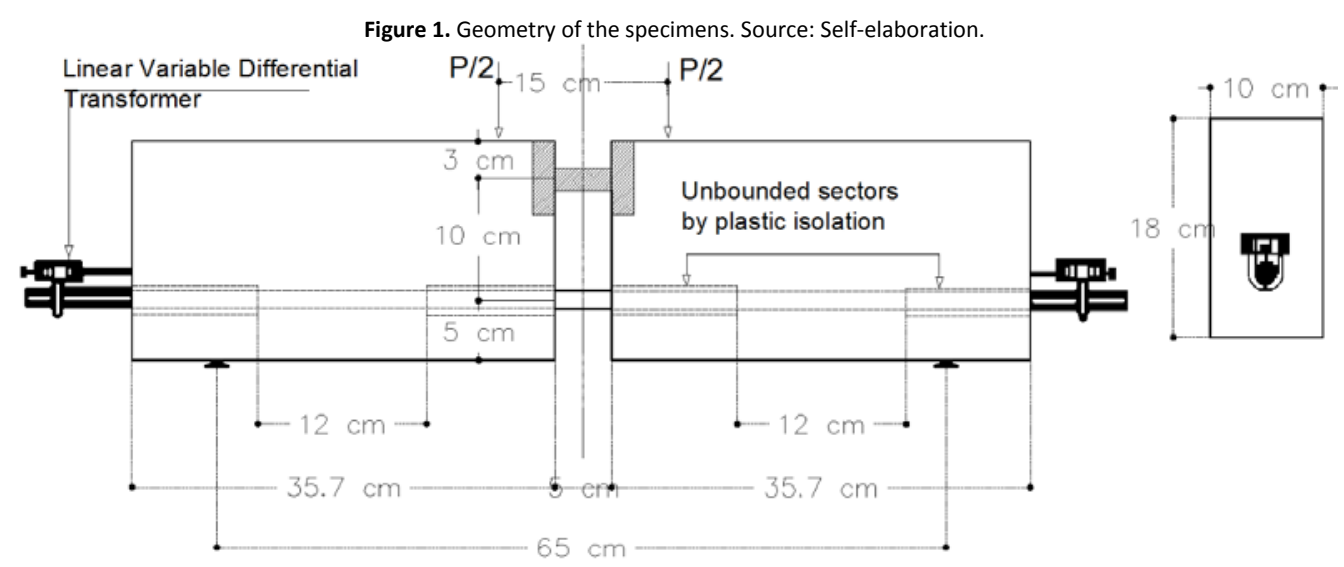

The beam is isostatic supported on rollers, the load is applied gradually and continuously to successive levels, corresponding to 0; 80; 160; 240; etc., MPa strength in the bar. Each load increment is performed 30 seconds, and each load level remains constant during the time required in order to stabilize the strains and displacements at maximum duration of two minutes. To measure the displacement of the bar at the beam ends, LVDT (Linear Variable Differential Transformer) $\pm 5 \mathrm{~mm}$ sensors are used; the machine used is a servo-controlled universal automatic metal gate system. The test configuration is showed in Figure 2.

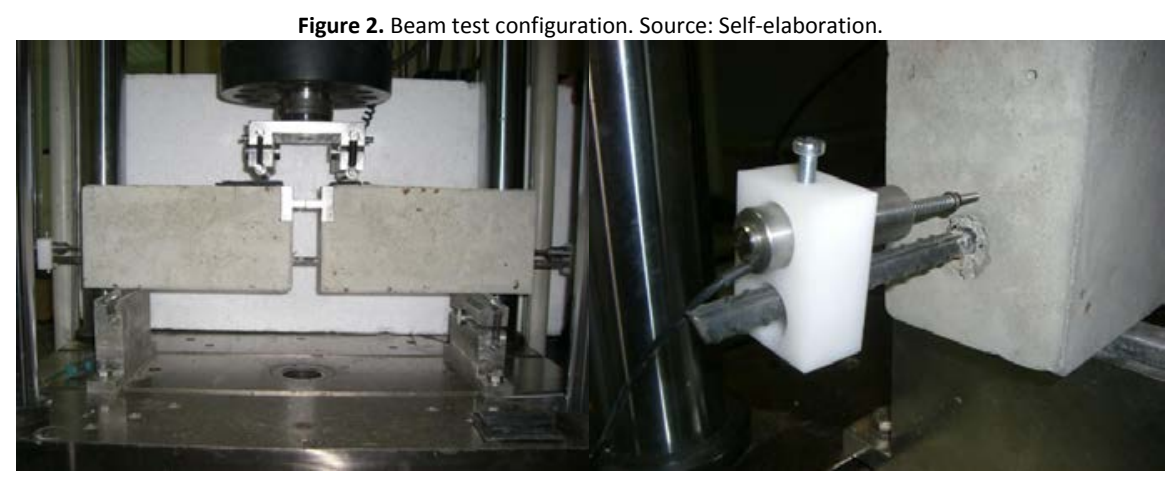

Each beam has two results, one for each half. The test starts with the load application by levels, once the first half fail the load is suspended and the load machine is controlled by position to avoid crushing test. There is a load loss, but the position is kept constant, to enable the test on the other half. To perform the test on the second half of the beam is necessary to fix the movement on the first half, as showed in Figure 3. To ensure the safety of the test and to control the movement, an LVDT was installed in the clamp. If any displacement was detected, the test was stopped immediately.

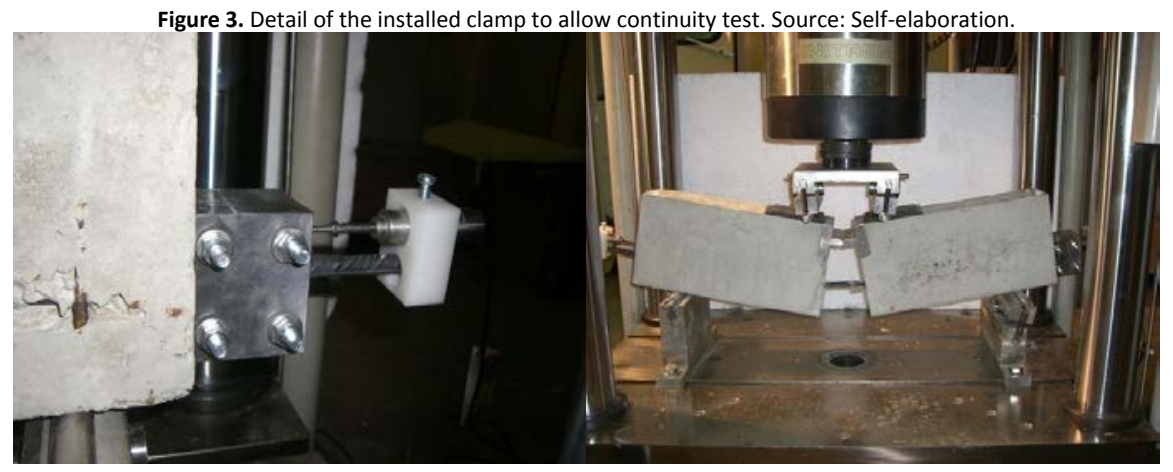




\section{Materials used for SCC and mix proportions}

The aggregates used in this study were calcareous geological origin (limestone) and was produced by crushing; this aggregates are the ones used for the daily concrete production. Four different sizes of aggregates were used: 12-20 mm, 5-12 $\mathrm{mm}, 0-4 \mathrm{~mm}$ and 0-2 $\mathrm{mm}$ (Table 1).

Table 1. Concrete mixture design proportions. Source: Self-elaboration.
\begin{tabular}{|l|l|l|l|l|}
\hline & C-35 & D-35 & C-60 & D-60 \\
\hline Sand 0-2 mm $\left(\mathrm{kg} / \mathrm{m}^{3}\right)$ & 115 & 115 & & \\
\hline Sand 0-4 mm $\left(\mathrm{kg} / \mathrm{m}^{3}\right)$ & 876 & 876 & 976 & 926 \\
\hline Fine gravel $5 / 12 \mathrm{~mm}\left(\mathrm{~kg} / \mathrm{m}^{3}\right)$ & 505 & 168 & 505 & 168 \\
\hline Gravel $12 / 20 \mathrm{~mm}\left(\mathrm{~kg} / \mathrm{m}^{3}\right)$ & 292 & 674 & 292 & 674 \\
\hline Water $\left(\mathrm{kg} / \mathrm{m}^{3}\right)$ & 182 & 182 & 182 & 182 \\
\hline Viscosity-Modifying Admixture $\left(\mathrm{g} / \mathrm{m}^{3}\right)$ & 2,7 & 2,7 & 2,7 & 2,7 \\
\hline Superplasticizer $\left(\mathrm{kg} / \mathrm{m}^{3}\right)$ & 8,73 & 8,73 & 8,73 & 8,73 \\
\hline Cement CEM II A-L 32,5 B-C (kg/m $\left.\mathrm{m}^{3}\right)$ & 380 & 380 & -- & -- \\
\hline Cement CEM II A-L 42,5R $\left(\mathrm{kg} / \mathrm{m}^{3}\right)$ & -- & -- & 450 & 450 \\
\hline Water/cement ratio & 0,479 & 0,479 & 0,404 & 0,404 \\
\hline
\end{tabular}

To perform a comparative study between the two types of granular skeleton, it was decided to minimize the number of variables to examine a fixed amount of cement, varying only the granular skeleton. For each of the two types of granular skeleton (continuous distribution mixtures $\mathrm{C}$ and discontinuous distribution mixtures $\mathrm{D}$ ), two levels of strength ( $35 \mathrm{MPa}$ and $60 \mathrm{MPa}$ ) were studied. This allows covering a broad spectrum of possible applications. The proportions of the concrete mixture designs are given in Table 1.

The mixing process was as follows. (1) Pour the aggregates and cement, and dry mix for a few seconds, (2) Pour the water (leaving 2 L out for reserve), (3) Mix for $1 \mathrm{~min}$, (4) Pour the viscosity-modifying admixture with a little water, (5) Mix for 1 min, (6) Pour the superplasticizer with the remaining water and (7) Mix for $4 \mathrm{~min}$. In total, 20 concrete batches of $150 \mathrm{~L}$ each were fabricated, totalizing $3,5 \mathrm{~m}^{3}$ of concrete poured into 420 specimens without any vibration. For each batch, the slump flow test was carried out for control purposes. Five batches of each mixture were made consecutively by the same operators to reduce any type of variation.

To characterize SCC in a fresh state, the following tests were performed according to UNE Standards: slump flow (UNE-EN 12350-8, 2011), J-ring (UNE-EN 12350-12, 2011), density (UNE-EN 12350-6, 2009) and occluded air (UNE-EN 12350-7, 2010). In order to define SCC in a hardened state, some tests were performed, according to UNE Standards to obtain the following mechanical properties: compressive strength (UNE 12390-3, 2009), modulus of elasticity (UNE-EN 12390-13, 2014), tensile strength (UNE 12390-6, 2010) and bond strength (UNE 36740, 1998) (see Table 2). An IBERTEST MHE series and an INSTRON 8500 (Servo-hydraulic testing system with a stiff frame and under closed-loop control) were used to perform the bond strength test. The specimens have been filled without any vibration, covered with plastic film for 24 hours. The beams have been transported to a climatic chamber (temperature $=20^{\circ} \mathrm{C}$ and relative humidity $=50 \%$ ) until the test date.

\section{Results and discussion}

Table 2 shows the characterization results for the different mix design. The results were calculated by the average of the specimens tested, 3 to 6 depending on the test. Slump flow tests were performed for all mixtures, and its value was used as a self-compactability reference parameter. Note that the continuous distribution skeleton (C) show higher diameters in 
the slump flow test, reflecting greater flow easiness, which may be because the continuous granular skeleton has a greater amount of paste (cement and sand) coating the coarse particles, allowing them to flow more easily. On the other hand, the discontinuous distribution skeleton (D) show a lower amount of paste and a greater amount of coarse aggregate. This causes an interlock effect among the particles and, ultimately, causes them to have a smaller diameter in the slump flow test.

Table 2. SCC characterization. Source: Self-elaboration.

\begin{tabular}{|c|c|c|c|c|}
\hline & C35 & C60 & D35 & D60 \\
\hline Slump flow (cm) & 68 & 69 & 60 & 62 \\
\hline Slump flow with J-ring (cm) & 68 & 66.5 & 56.5 & 59.5 \\
\hline Density (kg/m ${ }^{3}$ ) & 2270 & 2300 & 2300 & 2323 \\
\hline Occluded air (\%) & 3 & 2.4 & 2.9 & 2.0 \\
\hline 3 day - compressive strength (MPa) & 32.9 & 43.9 & 29.1 & 42.7 \\
\hline 7 day - compressive strength (MPa) & 36.0 & 49.9 & 35.5 & 48.5 \\
\hline 3 day - compressive strength (MPa) & 42.7 & 57.0 & 40.9 & 55.7 \\
\hline 7 day - Modulus of elasticity (GPa) & 32.4 & 37.0 & 31.3 & 36.5 \\
\hline 28 day - Modulus of elasticity (GPa)) & 35.8 & 39.6 & 34.5 & 38.0 \\
\hline 3 day - Splitting tensile Strength (MPa) & 2.9 & 3.7 & 3.1 & 3.4 \\
\hline 7 day - Splitting tensile Strength (MPa) & 3.8 & 3.7 & 3.4 & 3.5 \\
\hline 28 day - Splitting tensile Strength (MPa) & 3.9 & 5.2 & 3.5 & 4.6 \\
\hline
\end{tabular}

The J-ring slump flow test was performed in the first batch of each mix design. In general, the SCC flowed homogeneously between the ring bars without any blocking effect. The density and occluded air were assessed in fresh concrete in the first batches for the C-60, D-35 and D-60 and in the second batch for the C-35 design because the slump flow for this mixture was very high and was discharged.

Note that the density is homogeneous for all of the series. As expected, the values on the order of $2300 \mathrm{~kg} / \mathrm{m}^{3}$ for these concretes are because they have a greater amount of paste than a conventional concrete, whose density is on the order of $2400 \mathrm{~kg} / \mathrm{m}^{3}$. Regarding entrapped air, the results are lower values in all of the cases, showing the relationship that the greater the fluidity of concrete, the greater the slump flow extension and the less the entrapped air content.

The continuous distribution design of concretes show values of modulus of elasticity slightly higher than the discontinuous ones for all the ages and strengths. Discontinuous granular skeleton has $45 \mathrm{~kg} / \mathrm{m}^{3}$ more coarse aggregate than the continuous one. Due to the effect of coarse aggregate on the stiffness of concrete, one would anticipate a greater modulus of elasticity in concretes with discontinuous granular skeleton. This could be because the packing of the continuous granular skeleton provides a stiffer structure with higher modulus of elasticity. Anyway, hardened state results are similar for both granular skeletons at same strength, which allows a comparative analysis between the series.

\section{Beam test methodology}

In the methodology used to perform the beam test, two parameters are obtained: the bond stress $\left(\sigma_{\text {stress }}\right)$ and the bond strength $\left(\sigma_{\text {strenght }}\right)$. The specific procedure details are:

- Corrugated steel reinforcing bar of $12 \mathrm{~mm}$ diameter, similar in all beams;

- The SCC concrete was poured in horizontal position without any vibration;

- Test dates: 3,7 and 28 days;

- 2 beams tested for each date and mix proportions; 
- Neoprene plates $(5 \mathrm{~mm})$ and metal plates are used between the upper support beams in order to reduce friction

- The bond stress $\left(\sigma_{\text {stress }}\right)$ is calculated by averaging stress values resulting from steel reinforcing bar displacements of $0.01,0.1$ and $1 \mathrm{~mm}$;

- The bond strength $\left(\sigma_{\text {strength }}\right)$ is the maximum stress sustained by the beam or the stress corresponding a steel reinforcing bar displacement of $3 \mathrm{~mm}$;

- The maximum load applied in the beam ( $\mathrm{P}_{\text {breaking }}$ ) is the load corresponding to bond loss by displacement of the steel reinforcing bar.

Results

\section{Experimental results}

Table 3 contains the results of bond stress $\left(\sigma_{\text {stress }}\right)$ and bond strength $\left(\sigma_{\text {strength }}\right)$, as well as the maximum load applied in the beam ( $P_{\text {breaking }}$ ) and the coefficient of variation ( $C V$ in brackets). Figure 4 shows the results graphically. The trend curves were fitted using the nonlinear least squares approach.

\begin{tabular}{|c|c|c|c|c|c|c|c|c|c|}
\hline & \multicolumn{3}{|l|}{3 days } & \multicolumn{3}{|l|}{7 days } & \multicolumn{3}{|l|}{28 days } \\
\hline & $\begin{array}{l}\sigma_{\text {stress }} \\
(C V)\end{array}$ & $\begin{array}{l}\sigma_{\text {strength }} \\
(C V)\end{array}$ & $\begin{array}{l}\mathbf{P}_{\text {breaking }} \\
(C V)\end{array}$ & $\begin{array}{l}\sigma_{\text {stress }} \\
(C V)\end{array}$ & $\begin{array}{l}\sigma_{\text {strength }} \\
(C V)\end{array}$ & $\begin{array}{l}\mathbf{P}_{\text {breaking }} \\
(C V)\end{array}$ & $\begin{array}{l}\sigma_{\text {stress }} \\
(C V)\end{array}$ & $\begin{array}{l}\sigma_{\text {strength }} \\
(C V)\end{array}$ & $\begin{array}{l}\mathbf{P}_{\text {breaking }} \\
\text { (CV) }\end{array}$ \\
\hline C35 & \begin{tabular}{|l}
6,23 \\
$(13,7 \%)$ \\
\end{tabular} & $\begin{array}{l}11,58 \\
(23,9 \%)\end{array}$ & $\begin{array}{l}41,90 \\
(23,9 \%)\end{array}$ & $\begin{array}{l}8,09 \\
(8,2 \%) \\
\end{array}$ & $\begin{array}{l}12,98 \\
(4,2 \%)\end{array}$ & $\begin{array}{l}46,98 \\
(4,2 \%) \\
\end{array}$ & $\begin{array}{l}7,28 \\
(5,2 \%) \\
\end{array}$ & $\begin{array}{l}13,15 \\
(15,3 \%) \\
\end{array}$ & $\begin{array}{l}47,60 \\
(15,3 \%) \\
\end{array}$ \\
\hline D35 & $\begin{array}{l}6,91 \\
(7,8 \%) \\
\end{array}$ & $\begin{array}{l}13,02 \\
(13,9 \%) \\
\end{array}$ & $\begin{array}{l}47,12 \\
(13,9 \%) \\
\end{array}$ & $\begin{array}{l}8,23 \\
(11,9 \%) \\
\end{array}$ & $\begin{array}{l}13,69 \\
(14,6 \%) \\
\end{array}$ & $\begin{array}{l}49,53 \\
(14,6 \%) \\
\end{array}$ & $\begin{array}{l}8,91 \\
(9,6 \%) \\
\end{array}$ & $\begin{array}{l}14,32 \\
(1,3 \%)\end{array}$ & $\begin{array}{l}51,83 \\
(1,3 \%) \\
\end{array}$ \\
\hline $\mathrm{C} 60$ & $\begin{array}{l}9,30 \\
(4,3 \%) \\
\end{array}$ & $\begin{array}{l}14,29 \\
(2,3 \%) \\
\end{array}$ & $\begin{array}{l}51,71 \\
(2,3 \%) \\
\end{array}$ & $\begin{array}{l}10,68 \\
(0,0 \%) \\
\end{array}$ & $\begin{array}{l}16,03 \\
(0,0 \%) \\
\end{array}$ & $\begin{array}{l}58,01 \\
(0,0 \%) \\
\end{array}$ & $\begin{array}{l}9,82 \\
(10,8 \%)\end{array}$ & $\begin{array}{l}16,82 \\
(3,0 \%) \\
\end{array}$ & $\begin{array}{l}60,88 \\
(3,0 \%) \\
\end{array}$ \\
\hline D60 & $\begin{array}{l}6,11 \\
(7,2 \%)\end{array}$ & $\begin{array}{l}12,34 \\
(3,3 \%)\end{array}$ & $\begin{array}{l}44,65 \\
(3,3 \%)\end{array}$ & $\begin{array}{l}10,84 \\
(11,2 \%)\end{array}$ & $\begin{array}{l}15,86 \\
(17,1 \%)\end{array}$ & $\begin{array}{l}57,41 \\
(17,1 \%)\end{array}$ & $\begin{array}{l}9,70 \\
(0,0 \%)\end{array}$ & $\begin{array}{l}16,08 \\
(0,0 \%)\end{array}$ & $\begin{array}{l}58,21 \\
(0,0 \%)\end{array}$ \\
\hline
\end{tabular}

Figure 4. Bond test results a) $\sigma$ stress

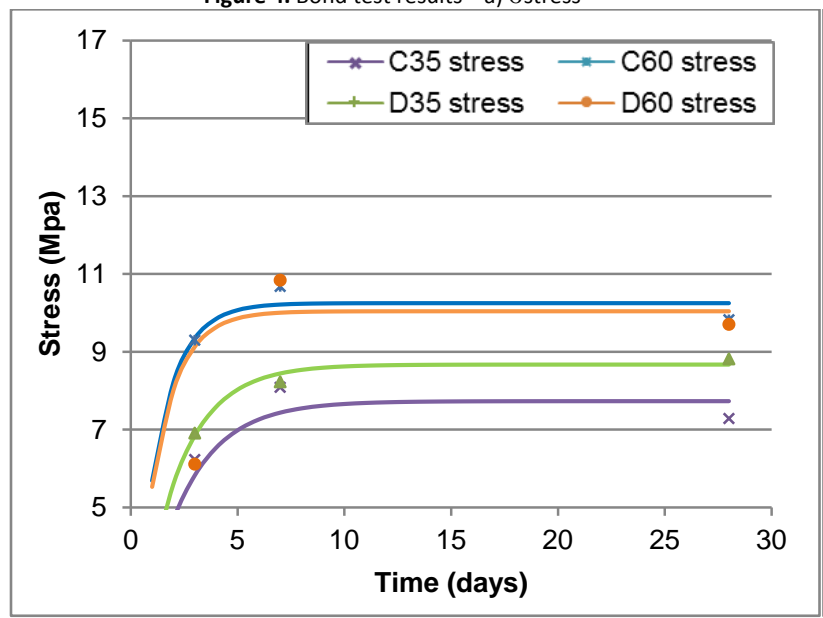

b) $\sigma$ strength. Source: Self-elaboration.

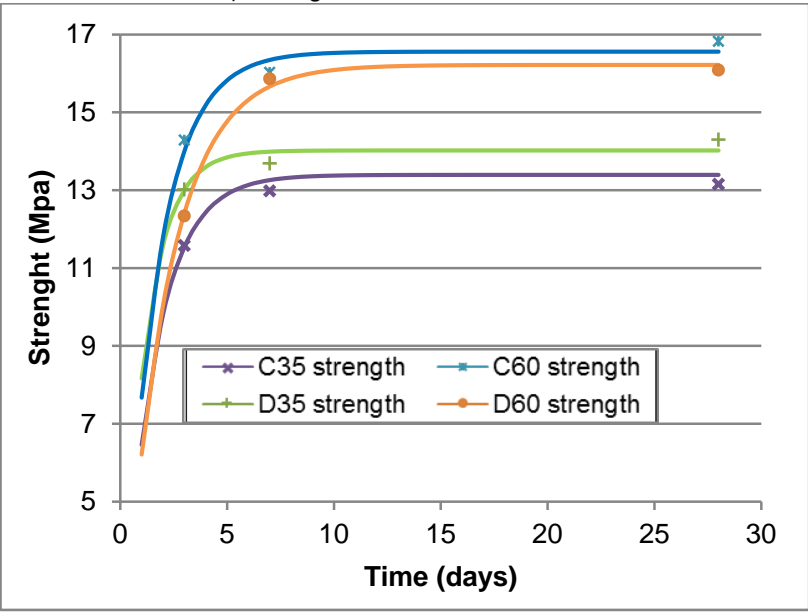

The results show that granular skeleton has no influence on the results of bond because the same strength series presented similar values. Moreover, in the series of low strength (35 MPa), the discontinuous skeleton (D) has achieved a slightly higher bond stress, while in the high-resistance series, the results alternate. In either case, the differences are representative. These differences may be related to adherence mechanisms present in each case. In low-strength concretes ( $35 \mathrm{MPa}$ ), the difference between the two granular skeletons ( $C$ and $D$ ) may be associated with mechanical 
bonding. Therefore, the discontinuous granular skeleton, presenting a higher coarse aggregate content, have a higher mechanical bonding. However, the series of higher strength (60 MPa) can be associated with a greater contribution of bond mechanism acting by means of adherence. In this case, the continuous granular skeleton has a greater proportion of adherence by bond mechanism due to its greater amount of paste (more fineness due to the higher content of sand).

Likewise, regardless of mechanical strength, all mix proportions exhibits rapid changes in bond behavior, reaching at 7 days $95 \%$ of the bond stress at 28 days. The same trend line was observed in bond strength, which difference is the order of magnitude. It is important to note in performing the tests a brittle fracture adherence mechanism was observed, because the beam passed quickly from a condition of stability without deformation to an excessive deformation with bond rupture. This comportment committed in many cases, conducting the test on the second side of the beam (according to UNE 36740:1998, the 2 sides of each beam are tested). Finally this study shows that SCC shows bond stress values of 7 to $10 \mathrm{MPa}$, which allows more precision to structural design.

\section{Conclusions}

Based on the beam test, this paper studies the bond behavior between reinforcement and self-consolidating concrete with two different granular skeleton. The main conclusions are as follows:

- The beam test can be used on anchorage length design. The test allows comparison between different studies, since it does not depend on the test conditions.

- The SCC studied showed a rapid evolution of adherence, achieving at 7 days $95 \%$ of bond strength at 28 days.

- Concerning bond strength results, granular skeleton apparently has no significant influence on this property because the series of similar strength have similar values. This may be due to opposing factors caused by different bonding mechanisms; on the one hand, the discontinuous skeleton may have increased mechanical bonding due to the higher content of coarse aggregate. However, the continuous skeleton may have increased adhesion due to the greater amount of paste (more binders due to the higher content of sand).

Acknowledgments

The authors wish to thank Promotora del Mediterráneo S.A. (PROMSA) and the Secretariat of State for Research, Development and Innovation of Spain for the support and funding granted for this project. Special thanks to the technicians of the Structure Technology Laboratory Luis Agulló of Barcelona Tech. 
AENOR. (1998). AENOR: Norma UNE 36740:1998. Retrieved 16 October, 2014, from: Http://www.aenor.es/.

AENOR. (2009a). AENOR: Norma UNE-EN 12350-6:2009. Retrieved 16 October, 2014, from: Http://www.aenor.es

AENOR. (2009b). AENOR: Norma UNE-EN 12390-3:2009. Retrieved 16 October, 2014, from: Http://www.aenor.es

AENOR. (2010). AENOR: Norma UNE-EN 12390-6:2010. Retrieved 16 October, 2014, from: Http://www.aenor.es

AENOR. (2011a). AENOR: Norma UNE-EN 12350-12:2011. Retrieved 16 October, 2014, from: Http://www.aenor.es

AENOR. (2011b). AENOR: Norma UNE-EN 12350-8:2011. Retrieved 16 October, 2014, from: Http://www.aenor.es

AENOR. (2014). AENOR: Norma UNE-EN 12390-13:2014. Retrieved 16 October, 2014, from: Http://www.aenor.es

Almeida Filho, F. M., Barragán, B. E., Casas, J. R., \& El Debs, A. L. H. C. (2008). Variability of the bond and mechanical properties of self-compacting concrete. Ibracon Structure and Materials Journal, 1(1), 31-43.

Collepardi, M., Borsoi, A., Collepardi, S., \& Troli, R. (2005). Strength, shrinkage and creep of SCC and flowing concrete. In Shah SP (Ed.), Proceedings of second North American conference on the design and use of self-consolidating concrete and fourth international RILEM symposium on selfcompacting concrete. (pp. 911-919). Chicago.

Desnerck, P., Taerwe, L., \& De Schutter, G. (2007). Experimental determination of Bond strength of reinforcing bars in self-compacting concrete. In G. D. S. P. Desnerck, L. Taerwe (Ed.), 5th International RILEM Symposium on Self-Compacting Concrete : SCC 2007 (pp. 659-664). Ghent.

Garzón Reyes, F. E., Almeida Filho, F. M. de, El Debs, M. K., \& El Debs, A. L. H. de C. (2008). Estudo da aderência entre barras de aço e concretos autoadensáveis e concretos convencionais submetidos a ações cíclicas e monotônicas em modelos de arrancamento. In Anais do $50^{\circ}$ Congresso Brasileiro do Concreto. Salvador.

Gibbs, J. C., \& Zhu, W. (1999). Strength of hardened self-compacting concrete. In Å. Skarendahl and Ö. Petersson (Ed.), 1st International RILEM Symposium on Self-Compacting Concrete : Stockholm, Sweden, September 13-14, 1999 (pp. 199-209). Stockholm.

Herrero, C. (2000). Estudio comparativo de las propiedades de adherencia de cordones de pretensado en elementos prefabricados de hormigones de altas prestaciones iníciales. PHD Thesis. La Coruña University. La Coruña, Spain.

König, G., Holschemacher, K., Dehn, F., \& Weibe, D. (2001). Self-Compacting Concrete - Time Development of Material Properties and Bond Behavior. In Proceedings of 2nd International Symposium on Self-Compacting Concrete (pp. 507-516). Tokyo.

Mori, M.; Aguado, A.; \& Renófilo, A. (2004) "Aderência entre concreto auto-adensável de alta resistência e armadura" Acta Scientiarum. Technology. Maringá, v. 26, no. 2, p. 135-139

Mori, M., \& Aguado, A. (2005). Adherencia en hormigones autocompactable de alta resistencia. In III Congreso de ACHE de Puentes y Estructuras. Zaragosa.

RILEM TC. (1992). Comp012 AAC 8.1 Pull-out test for reinforcement, 1992. In Rilem (Ed.), RILEM Technical Recommendations for the Testing and Use of Construction Materials.

Santos, A. C. P., Ortiz-Lozano, J. A., Villegas, N., \& Aguado, A. (2015). Experimental study about the effects of granular skeleton distribution on the mechanical properties of self-compacting concrete (SCC). Construction and Building Materials, 78, 40-49. https://doi.org/10.1016/j.conbuildmat.2015.01.006

Schiessl, A., \& Zilch, K. (2001). The Effects of the Modified Composition of Self-Compacting Concrete on Shear and Bond Behavior. In K. Ozawa, M. Ouchi, \& TokyōDaigaku. (Eds.), Proceedings of the Second International Symposium on Self-compacting Concrete (p. 742). Tokyo.

Silva, Y., Burgos, D., Valencia, W., Delvasto, S., \& Alvarez, J. (2013). Concretos autocompactantes a partir de lodo calcáreo de la industria papelera. Revista de La Construcción, 12(2), 166-176. https://doi.org/10.4067/S0718-915X2013000200013

Sonebi, M., \& Bartos, P. J. M. (1999). Hardened SCC and its bond with reinforcement. In A. Skarendahl \& O. (Örjan) Petersson (Eds.), 1st International RILEM Symposium on Self-Compacting Concrete (p. 786). Stockholm.

Valcuende, M., \& Parra, C. (2009). Bond behaviour of reinforcement in self-compacting concretes. Construction and Building Materials, 23(1), 162-170. https://doi.org/10.1016/j.conbuildmat.2008.01.007

Wang, G. (2005). Bond Behaviors of Self-Compacting Concrete. In SCC'2005-China - 1st International Symposium on Design, Performance and Use of SelfConsolidating Concrete (pp. 465-471). Changsha, China.

Zhu, W., Sonebi, M., \& Bartos, P. J. M. (2004). Bond and interfacial properties of reinforcement in self-compacting concrete. Materials and Structures, 37(7), 442-448. https://doi.org/10.1007/BF02481580 